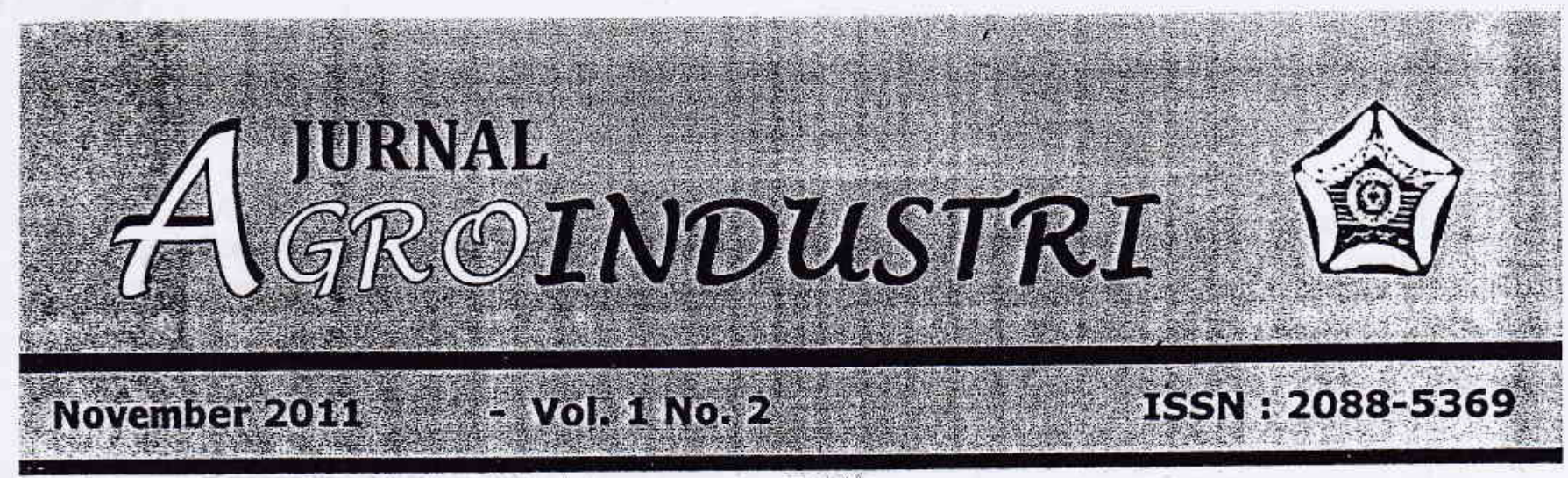

ANALISIS PENURUNAN KUALITAS MINYAK GORENG CURAH SELAMA PENGGORENGAN KERUPUK JALIN

Wuri Marsigit, Budiyanto dan Mukhsin

PERSEPSI MASYARAKAT TERHADAP PENGGUNAAN BRIKET CANGKANG KELAPA SAWIT SEBAGAI BAHAN BAKAR ALTERNATIF PENGGANTI MINYAK TANAH

Hasan Basri Daulay, Lukman Hidayat dan Agung Sudrajad

APIIKASI STARTER KULTUR MURNI PADA PEMBUATAN DURIAN FERMENTASI

Hasanuddin

KAJIAN PEGGUNAAN BERBAGAI JENIS BIOBRIKET SEBAGAI ALTERNATIF PENGGANTI MINYAK TANAH UNTUK RUMAH TANGGA

Budiyanto, Pandu Imam dan Sari Puspita Ningsih

PENDUGAAN UMUR SIMPAN DAN TINGKAT PENERIMAAN KONSUMEN PADA PEMBUATAN PRODUK BIOFARMAKA BERBASIS TERIPANG PASIR (Holothuria scabra) SEBAGAI ANTI FUNGI

Kumia Harlina Dewi, Laili Susanti, Devi Silsia, Irawanto

PENGARUH EKSTRAKSI DAN JENIS BAHAN PENGIKAT TERHADAP PERMEN TABLET BUAH MENGKUDU (Morinda citrifolia)

Lina Widawati

PENGARUH LUMPUR SAWIT FERMENTASI DENGAN SUPLEMENTASI ASAM AMINO LISIN, METIONIN, TRIPTOPAN SELAMA PRODUKSI TERHADAP PERFORMANS DAN KUALITAS INTERNAL SERTA KADAR KOLESTEROL TELUR AYAM RAS

Yosi Fenita dan Desia Kaharuddin
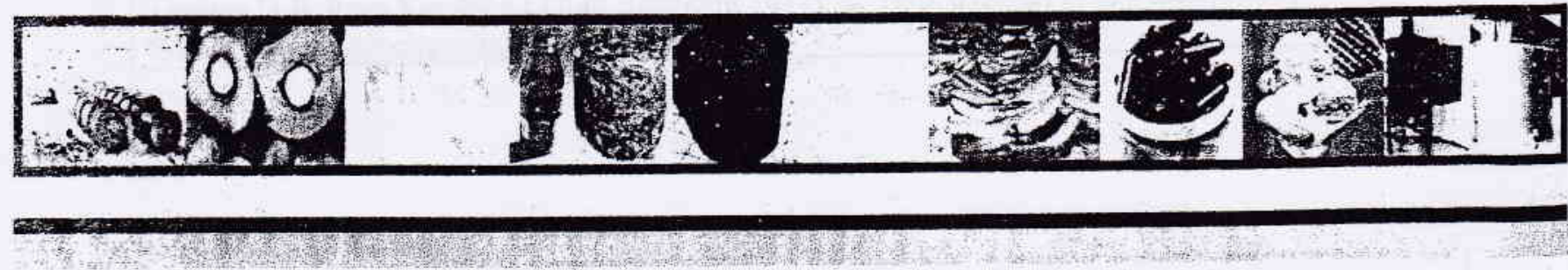


\section{KATA PENGANTAR}

Alhamdulillah, berkat dan rahmatNYA Penerbitan Jurnal Agroindustri nomor kedua dapat diselesaikan. Jurnal Agroindustri merupakan upaya meningkatkan media komunikasi ilmiah tentang Agroindustri dan Teknologi Pertanian, berisikan karya ilmiah berupa hasil penelitian, telaah pustaka serta pemikiran, bidang ilmu Teknologi Pertanian. Jurnal Agroindustri diharapkan memberi manfaat bagi para pengajar di Perguruan Tinggi, peneliti dan profesi untuk mempublikasikan karya ilmiahnya serta menjadi rujukan bagi pengguna.

Pada penerbitan ini adalah edisi no dua pada volume 1, topik karya ilmiah yang disajikan sudah bervariasi dari edisi no 1 . Pada edisi ini, terdapat dúa penulis yang bukan berasal dari Jurusan Teknologi Pertanian Universitas Bengkulu. Diharap kedepan akan lebih banyak karya ilmiah dari Peneliti Universitas lain untuk memperkaya khasanah keilmuan. Sebagai upaya untuk dapat memberikan manfaat yang luas bagi komunitas ilmiah pada bidang Ilmu Teknologi Pertanian, jumal ini akan kami distribusikan pada masyarakat ilmiah secara nasional. Selain itu, kami berharap peran serta, masukan dan partisipasi serta kritik dan saran yang membangun dari semua fihak.

Pada kesempatan ini, tim editor mengucapkan banyak terima kasih kepada Rektor Universitas Bengkulu dan Dekan Fakultas Pertanian Universitas Bengkal atas semua bantuan baik materil maupun spirit serta fasilitas atas penerbitan Jurnal Agroindustri Edisi perdana ini. Terima kasih juga disampaikan pada penulis atas kepercayaan mempublikasikan karya ilmiahnya. Serta ucapan terima kasih pada pembaca, semoga bermanfaat bagi semua

Bengkulu, 30 November 2011

Tim Editor

"JURNAL AGROINDUSTRI"

Media Komunikasi Ilmiah Tentang Agroindusiri dan Teknologi Pertanian

PENERBIT:

Jurusan Teknologi Pertanian, Fakultas Pertanian Universitas Bengkulu

KETUA REDAKSI :

Dr. Ir. Kurnia Harlina Dewi, MSi

DEWAN REDAKSI :

Prof. Dr. Yuwana, MSc

Dra. Devi Silsia, MSi;

Ir. Hasanuddin, MSc;

Evanila Silvia, STP. MSi;

Drs. Syafnil, MSi;

Yessy Rosalina, STP. MSi;

\section{ALAMAT REDAKSI:}

Jurusan Teknologi Pertanian, Fakultas Pertanian Universitas Bengkulu, Gedung U J. Raya Kandang Limun Bengkulu 38371 A, Teip. 0736-211770 Pesawat 214, E-mail : teknologipertanianunib@yahoo.co.id 


\title{
ANALISIS PENURUNAN KUALITAS MINYAK GORENG CURAH SELAMA PENGGORENGAN KERUPUK JALIN
}

\author{
Wuri Marsigit, Budiyanto dan Mukhsin \\ Program Studi Teknologi Industri Pertanian, Jurusan Teknologi Pertanian \\ Fakultas Pertanian Universitas Bengkulu
}

\begin{abstract}
Abstrak
Selama penggorengan kualitas minyak mengalami penurunan kualitas yang dipengaruhi oleh uap yang dilepaskan dari bahan yang digoreng, suhu penggorengan, lama pemanasan/penggorengan dan komposisi bahan yang digoreng. Indikator kerusakan minyak goreng dapat diamati dari perubahan sifat fisika-kimianya, antara lain bilangan asam, kandungan asam lemak bebas (ALB) dan titik asap. Penelitian ini bertujuan untuk menganalisa pola perubahan kualitas minyak goreng curah selama penggorengan kerupuk jalin pada suhu di atas $190{ }^{\circ} \mathrm{C}$ selama 4 jam. Rancangan penelitian yang digunakan pada penelitian ini yaitu minyak goreng dengan penambahan ulang dan pengaruh lama waktu penggorengan selama 4 jam. Dilakukan pengambilan sampel setiap 0,5 jam penggorengan. Data ditampilkan dalam bentuk grafik dan dianalisa secara deskriptif. Hasil penelitian menunjukkan, setelah penggorengan kerupuk jalin selama 4 jam pad suhu di atas $190{ }^{\circ} \mathrm{C}$, pola perubahan kualitas minyak goreng curah terlihat meningkat tidak linier pada perubahan bilangan asam dan asam lemak bebas. Dilain pihak, pola perubahan kualitas minyak goreng curah terlihat menurun tidak linier pada titik asap. Peningkatan dan penurunan yang tidak linier ini disebabkan karena terjadi penambahan minyak baru setiap satu jam sekali yang berfungsi untuk menstabilkan minyak goreng baik secara kualitas maupun kuantitas. Berdasarkan pengukuran kandungan bilangan asam, asam lemak bebas dan titik asap, diketahui bahwa minyak goreng curah masih layak pakai adalah pada 40 kali penggorengan selama 2.5 jam dengan kerupuk jalin sebanyak $100 \mathrm{~kg}$. Hal ini mengindikasikan bahwa kandungan bilangan asam $2.42 \%$ masih di bawah batas maksimal yaitu $2.5 \%$.
\end{abstract}

\section{PENDAHULUAN}

Minyak goreng merupakan salah satu dari sembilan bahan pokok di Indonesia. Sebagai salah satu kebutuhan pokok, minyak goreng selalu tersedia di setiap rumah tangga. Minyak dalam penggorengan berfungsi sebagai medium penghantar panas, menambah rasa gurih dan menambah nilai kalori dalam bahan pangan (Blumenthal, 1991 dan Winarno, 1997).

Selama penggorengan kualitas minyak mengalami penurunan (Blumenthal, 1991; Jacobson, 1991; White, 2007). Faktor-faktor yang mempengaruhi penurunan kualitas minyak dalam ketel penggorengan diantaranya adalah uap yang dilepaskan dari bahan yang digoreng, suhu penggorengan, lama pemanasan/penggorengan dan komposisi bahan yang digoreng (Ketaren, 1986). Penambahan minyak segar pada saat penggorengan untuk menggantikan minyak yang terserap pada bahan akan memperbaiki/mengurangi tingkat kerusakan minyak yang telah terjadi (Berger, 2005).

Minyak goreng yang paling banyak digunakan di Indonesia adalah minyak sawit (lebih dari 70 persen), diikuti dengan minyak kelapa (Anonim, 
2002). Minyak goreng yang beredar di pasaran dapat berupa minyak goreng yang telah bermerk ataupun dalam bentuk curahan (minyak curah).

Dalam proses penggorengan kerupuk minyak yang digunakan adalah minyak goreng curah yang dilakukan penambahan ulang secara berkala apabila persediaan pada kuali penggorengan telah terbatas atau telah menipis. Pada saat proses penggorengan berlangsung tejadi penetrasi panas masuk ke bahan dari minyak yang merubah karakteristik bahan pangan yang digoreng (Ketaren, 1986). Seperti perubahan struktur fisik bahan pangan, menambah nilai kalori serta memberi cita rasa gurih pada makanan yang digoreng (Atmojo, 2007). Tetapi apabila panas pada saat penggorengan berlangsung tidak dikendalikan, maka akan terjadinya reaksi kimia yang menyebabkan hasil gorengan yang tidak dinginkan. Ketika bahan makanan dimasukkan dalam panci temperatur akan turun dengan cepat, temperatur turun tidak hanya tergantung pada jumlah bahan yang ada, tetapi juga jumlah kandungan air dalam bahan yang digoreng. Kandungan air yang keluar dari bahan dapat menyebabkan reaksi hidrolisa terjadi (Siahaan, 2004).

Selama pemanasan minyak goreng terjadi kerusakan, sifat fisiokimia minyak goreng juga berubah selama penggorengan tetapi belum diketahui bagaimana pola perubahan tersebut pada minyak goreng curah yang sudah digunakan berulangkali dan dilakukan penambahan minyak baru

\section{METODE PENELITIAN}

Penelitian ini dilaksanakan di Laboratorium Teknologi Pertanian Fakultas Pertanian Universitas Bengkulu pada bulan November 2009 s/d November 2010. Minyak goreng curah yang diperoleh dari perusahaan kerupuk 'Assyifa' yang berlokasi Jl. Jenggalu No. 04 RT. 10 RW. 01 Kelurahan Tebeng, yang dilakukan penambahan ulang selama penggorengan kerupuk jalin.

Metode penelitian dilakukan dengan cara minyak goreng curah yang digunakan untuk menggoreng kerupuk jalin dan dilakukan pencampuran dengan minyak lama dengan perbandingan $1: 3$, satu bagian untuk minyak lama dan 3 bagian untuk minyak baru. Penambahan minyak dilakukan setiap selang 1 jam dengan jumlah $2 \mathrm{~kg}$ setiap penambahan. Dilakukan pengambilan sampel setiap setengah jam sekali selama 4 jam. Variabel yang diamati adalah bilangan asam, asam lemak bebas dan titik asap. Hasil ditampilkan dalam bentuk grafik kemudian dianalisa secara diskriptif untuk mengetahui pola perubahan parameter yang diamati dan dilakukan analisa korelasi untuk melihat hubungan antara satu variabel dengan variabel lainnya pada minyak goreng curah selama penggorengan empat jam.

\section{HASIL DAN PEMBAHASAN}

Hasil pengukuran kadar bilangan asam, asam lemak bebas dan titik asap minyak goreng curah yang telah dilakukan penggorengan kerupuk jalin selama 4 jam dan dilakukan pencampuran dan penambahan ulang.

Tabel 1. Tiga Parameter Kualitas Minyak Goreng Curah Selama Penggorengan Dengan Kerupuk Jalin

\begin{tabular}{ccccc}
\hline $\begin{array}{c}\text { Waktu } \\
(\text { jam) }\end{array}$ & $\begin{array}{c}\text { Jumlah } \\
\text { kerupuk } \\
\text { yang } \\
\text { digoreng } \\
(\mathbf{k g})\end{array}$ & $\begin{array}{c}\text { Bilangan } \\
\text { Asam } \\
(\%)\end{array}$ & $\begin{array}{c}\text { Asam } \\
\text { Lemak } \\
\text { Bebas } \\
(\%)\end{array}$ & $\begin{array}{c}\text { Titik } \\
\text { Asap } \\
\left({ }^{\mathbf{0}} \mathbf{C}\right)\end{array}$ \\
\hline 0.0 & 0 & 1.8981 & 0.8875 & 185.3333 \\
0.5 & 20 & 1.9448 & 0.9045 & 179.3333 \\
1.0 & 40 & 2.1412 & 1.0411 & 178.6667 \\
\hline
\end{tabular}




\begin{tabular}{ccccc}
\hline 1.5 & 60 & 2.1225 & 0.8363 & 177.3333 \\
2.0 & 80 & 2.4310 & 1.0752 & 173.3333 \\
2.5 & 100 & 2.4123 & 0.9387 & 172.6667 \\
3.0 & 120 & 2.6741 & 1.1947 & 171.3333 \\
3.5 & 140 & 2.6367 & 1.2117 & 162.0000 \\
4.0 & 160 & 3.5063 & 1.8261 & 160.6667 \\
\hline
\end{tabular}

Pola Perubahan Bilangan Asam Minyak Goreng Curah Selama Penggorengan Kerupuk Jalin

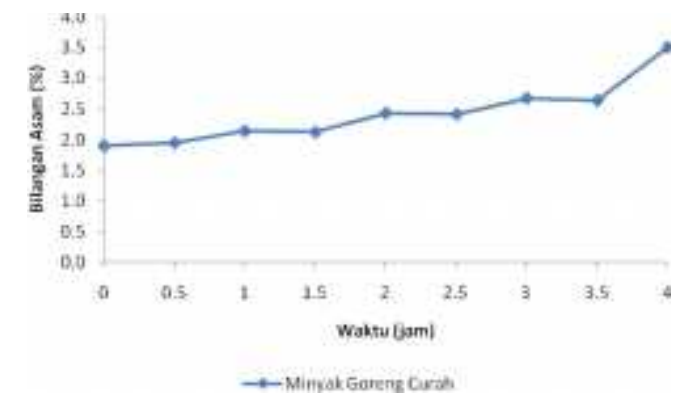

Gambar 1. Grafik perubahan bilangan asam selama penggorengan kerupuk jalin

Berdasarkan gambar 1 dapat diketahui kandungan bilangan asam terendah sebesar $1.89 \%$ pada waktu nol atau sebelum dilakukannya penggorengan. Tingginya kandungan bilangan asam disebabkan karena minyak goreng curah telah dilakukan pencampuran dengan minyak lama dengan perbandingan 1:3. Kandungan bilangan asam tertinggi minyak goreng curah terlihat pada waktu penggorengan setelah empat jam penggorengan yaitu sebesar $3.50 \%$ atau pada akhir penggorengan yang telah dilakukan 64 kali penggorengan kerupuk jalin dengan berat $160 \mathrm{~kg}$ pada suhu di atas $190{ }^{\circ} \mathrm{C}$.

Gambar 1 menunjukkan bahwa penggorengan kerupuk jalin dengan suhu yang tinggi dan semakin seringnya pengulangan dilakukan mempercepat peningkatan bilangan asam pada minyak goreng curah. Peningkatan bilangan asam dengan pertambahan waktu penggorengan menandakan bahwa minyak goreng curah mengalami kerusakan selama penggorengan. Kerusakan ini disebabkan oleh adanya suhu penggorengan yang tinggi dan adanya interaksi antara bahan yang digoreng dengan minyak sebagai penggoreng yang menyebabkan reaksi yang sangat kompleks, yaitu membentuk senyawa-senyawa volatile maupun nonvolatile (Moreira et al., dalam Kurniawan, 2008). Salah satu bentuk interaksi bahan dengan minyak dapat berupa reaksi hidrolsis. Selain proses hidrolisis selama penggorengan, juga terjadi reaksi oksidasi yang disebabkan kontak antara minyak goreng dengan udara yang ada di sekitar minyak penggorengan. Dalam penggorengan juga terjadi rekasi polimerisasi yang membentuk senyawa polimer, hal ini terbukti dengan terbentuknya bahan menyerupai gum yang mengendap di dasar tempat penggorengan (Ketaren, 1986).

Gambar 1 dapat dilihat bahwa bilangan asam meningkat dari $1.89 \%$ menjadi $3.50 \%$ atau penurunan kualitas minyak goreng curah yang dilihat dari peningkatan kandungan bilangan asam adalah sebesar $45.87 \%$. Minyak goreng curah tidak lanyak lagi untuk digunakan pada penggorengan setelah 3 jam, yaitu setelah dilakukan 48 kali penggorengan atau sebanyak $120 \mathrm{~kg}$ krupuk jalin. Hal ini karena telah melewati batas maksimal bilangan asam untuk minyak goreng yang digunakan untuk menggoreng yaitu 2,5\%. Dalam oparasi penggorengan akan dihentikan ketika minyak atau lemak yang digunakan untuk menggoreng telah melebihi batas maksimal angka asam (Berger, 2005).

Pola peningkatan bilangan asam minyak goreng selama empat jam penggorengan kerupuk jalin pada suhu di atas $190{ }^{0} \mathrm{C}$ terlihat meningkat naik dengan peningkatan yang tidak linier. Melihat keadaan tersebut ternyata penambahan minyak baru yang dilakukan setiap satu jam sekali dalam penggorengan kerupuk jalin dapat mengurangi peningkatan bilangan asam 
minyak goreng. Pengurangan bilangan asam ini tidak sampai turun menjadi seperti keadaan semula, hal ini terjadi karena penambahan minyak goreng secara berkala tidak mampu menurunkan bilangan asam yang disebabkan oleh pertambahan waktu dan pengulangan penggorengan kerupuk jalin yang begitu sering dilakukan. Selain menurunkan bilangan asam, minyak segar yang ditambahkan ke dalam kuali/ketel penggorengan juga berguna untuk menggantikan minyak yang hilang akibat diserap oleh bahan pangan yang digoreng, membantu menghambat kehilangan minyak akibat panas serta faktor lainnya (Ketaren, 1986).

Hubungan korelasi bilangan asam dengan titik asap diperoleh nilai koefesien korelasi (r) $=-0.89$, yang menandakan bahwa hubungan bilangan asam dengan titik asap memiliki hubungan yang berbanding terbalik, yaitu semakin naik kadungan bilangan asam maka semakin menurun titik asapnya.

\section{Pola Perubahan Kandungan Asam Lemak Bebas Minyak Goreng Curah Selama Penggorengan Kerupuk Jalin}

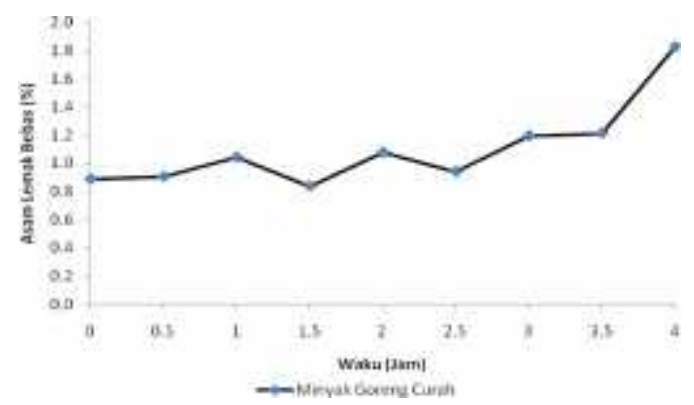

Gambar 2. Grafik perubahan asam lemak bebas selama penggorengan kerupuk Jalin

Pada gambar 2 dapat diketahui kandungan asam lemak bebas terendah minyak goreng curah yang dilakukan dengan waktu penggorengan kerupuk jalin selama empat jam, yakni sebesar
$0.83 \%$ pada waktu 1,5 jam atau setelah dilakukan 24 kali penggorengan kerupuk jalin dengan berat $60 \mathrm{~kg}$ pada suhu di atas $190{ }^{\circ} \mathrm{C}$, sedangkan asam lemak bebas tertinggi minyak goreng curah terlihat pada penggorengan setelah empat jam yaitu sebesar 1.82\% atau akhir penggorengan yang telah dilakukan 64 kali penggorengan kerupuk jalin dengan berat $160 \mathrm{~kg}$ pada suhu di atas $190{ }^{\circ} \mathrm{C}$.

Berdasarakan hasil pengukuran kandungan asam lemak bebas, tingginya kandungan FFA minyak goreng curah sebesar $0.88 \%$ pada waktu nol atau sebelum dilakukan penggorengan menunjukkan minyak goreng curah tersebut telah mendekati batas toleransi residu asam lemak bebas yang diperkenankan untuk minyak goreng, yaitu 1,0\% (Tseng, 1999). Tingginya kandungan asam lemak bebas ini juga disebabkan karena minyak goreng curah telah dilakukan pencampuran dengan minyak lama dengan perbandingan 1:3.

Gambar 2 menunjukkan Peningkatan asam lemak bebas terjadi pada penggorengan satu jam pertama yang telah dilakukan pengulangan penggorengan kerupuk jalin sebanyak 16 kali penggorengan dengan berat kerupuk jalin 16 x $2,5 \mathrm{~kg}$ atau $20 \mathrm{~kg}$ kerupuk jalin hingga akhir waktu penggorengan yang telah dilakukan 64 kali pengorengan kerupuk jalin atau sebanyak $160 \mathrm{~kg}$. Gambar 2 dapat dilihat bahwa asam lemak bebas meningkat dari $0.89 \%$ menjadi $1.83 \%$ atau penurunannya sebesar $51.40 \%$. Keruskan minyak terjadi setelah satu jam penggorengan, terlihat kandungan asam lemak bebas telah melewati batas maksimal $1 \%$. Minyak goreng curah tidak lanyak lagi untuk digunakan adalah pada penggorengan setelah 4 jam, yaitu setelah dilakukan 64 kali penggorengan atau sebanyak $160 \mathrm{~kg}$ krupuk jalin. Hal ini karena telah 
melewati batas maksimal asam lemak bebas untuk minyak goreng bekas dalam penggorengan yaitu $1,5 \%$.

Selama proses penggorengan yang dilakukan berulang secara nyata meningkatkan kandungan asam lemak bebas (Siahaan, 2004). Menurut Budiyanto (1996), terjadi tren peningkatan asam lemak bebas pada minyak kedelai dan minyak olein sawit selama 5 hari penggorengan. Peningkatan kandungan asam lemak bebas selama proses pengorengan disebabkan karena akibat terjadinya reaksi oksidasi dan hidrolisa minyak selama proses penggorengan (Budiyanto $d k k .$, 2008). Proses ini mempengaruhi perubahan mutu minyak selama penggorengan, oleh karena itu kualitas minyak adalah hal yang sangat penting untuk memperoleh makanan hasil penggorengan yang baik (Stevenson et al., 1984; Pokorny, 1999 dalam Navas et al., 2007).

Pola peningkatan kandungan asam lemak bebas minyak goreng curah selama empat jam penggorengan kerupuk jalin pada suhu di atas $190{ }^{\circ} \mathrm{C}$ meningkat naik dengan peningkatan yang tidak linier. Hal ini terjadi karena setiap satu jam sekali dilakukan penambahan minyak segar sebanyak 2 $\mathrm{kg}$. Penambahan minyak baru yang dilakukan setiap satu jam sekali dalam penggorengan kerupuk jalin dapat mengurangi peningkatan kandungan asam lemak bebas minyak goreng. Menurut Budiyanto (1996), bahwa penambahan minyak selama 5 hari penggorengan dengan palm olein mampu memperpanjang frying life yang ditunjukkan dengan kandungan FFA dibawah $0,5 \%$ pada akhir studi penggorengan. Penurunan kandungan asam lemak bebas terendah terlihat pada waktu setelah 1,5 jam penggorengan kerupuk jalin. Penurunan asam lemak bebas terjadi karena jumlah asam lemak bebas yang berubah menjadi senyawa lain menjadi lebih banyak dari pada asam lemak yang terbentuk. Menurut Janika (2008), semakin tinggi suhu dan lama waktu pemanasan, kandungan asam lemak bebas yang semula besar akan berkurang karena asam-asam lemak bebas menguap bersama zat-zat mudah menguap yang terkandung dalam minyak tersebut. Secara umum gambar 2 terlihat bahwa asam lemak bebas semakin lama semakin meningkat, hal ini terjadi karena penambahan minyak goreng secara berkala tidak mampu menurunkan asam lemak bebas yang disebabkan oleh pertambahan waktu dan pengulangan penggorengan kerupuk jalin yang begitu sering dilakukan.

Hubungan korelasi asam lemak bebas dengan bilangan asam diperoleh nilai koefesien korelasi $(r)=0.95$, yang menandakan bahwa semakin tinggi asam lemak bebas maka kadungan bilangan asam juga semakin meningkat. Menurut Ketaren (1996), bilangan asam merupakan ukuran dari jumlah asam lemak bebas, serta dihitung berdasarkan berat molekul dari asam lemak atau campuran asam lemak.

\section{Pola Perubahan Titik Asap Minyak Goreng Curah Selama Penggorengan Kerupuk Jalin}

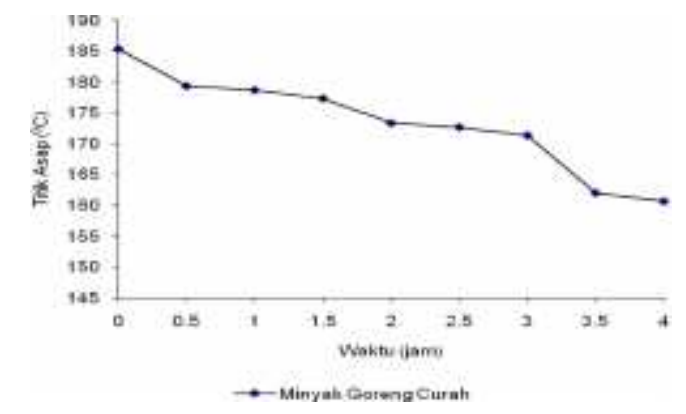

Gambar 3. Grafik perubahan titik asap selama penggorengan kerupuk 
Gambar 3 menunjukkan temperatur titik asap mengalami penurunan selama penggorengan. Berdasarkan gambar 3 dapat diketahui temperatur terendah minyak goreng curah yang dilakukan dengan penggorengan kerupuk jalin terlihat setelah empat jam penggorengan atau pada akhir penggorengan yang telah dilakukan 64 kali penggorengan kerupuk jalin dengan berat $160 \mathrm{~kg}$, yakni $160.66{ }^{0} \mathrm{C}$. Temperatur tertinggi minyak goreng curah terlihat sebelum terjadi penggorengan yaitu $185.33{ }^{\circ} \mathrm{C}$. Titik asap yang relatif kecil ini terjadi karena minyak goreng curah pada awal penggorengan dilakukan pencampuran dengan minyak lama dengan perbandingan 1:3.

Gambar 3 menunjukkan bahwa, semakin lama waktu pengorengan keupuk jalin, titik asapnya semakin turun. Menurut Hariskal (2008), minyak dengan titik asap yang rendah memiliki kandungan asam lemak bebas yang tinggi. Minyak yang teroksidasi karena kontak dengan udara, panas dan cahaya akan berdampak pada turunnya titik asap (Fauziah et al., 2005 dalam Ramini, 2008). Menurut Deane (2007), minyak yang telah teroksidasi karena terkena udara, panas dan cahaya akan mempunyai titik asap yang lebih rendah. Dengan menggunakan minyak berulang kali juga membuat asap lebih cepat dihasilkan (Elizabeth, 2002). Adanya titik asap menandakan bahwa minyak goreng curah tersebut mengalami kerusakan fisik.

Winarno (1986) menyebutkan bahwa mutu minyak goreng tergantung dari titik asapnya, yaitu suhu pemanasan minyak sampai terbentuk akrolein. Akrolein adalah sejenis aldehid yang dihasilkan dari pecahan Gliserol yang tidak diinginkan dan dapat menimbulkan rasa gatal pada tenggorokan (Wiley, 2009).
Pada gambar 3 dijelaskan bahwa kualitas minyak goreng semakin lama semakin turun yang telihat dengan semakin turunnya temperatur pada saat timbulnya asap. Minyak goreng curah tidak lanyak lagi untuk digunakan adalah pada penggorengan setelah 3,5 jam, yaitu setelah dilakukan 56 kali penggorengan atau sebanyak $140 \mathrm{~kg}$ krupuk jalin yang ditandai dengan titik asap di bawah batas toleransi minimal titik asap yakni $170{ }^{0} \mathrm{C}$. Menurut Jacobson (1991), batas umur pakai minyak goreng dibeberapa negara Eropa diindikasikan dengan terjadinya smoke point (titik asap) pada $170{ }^{0} \mathrm{C}$. Titik asap menurun dari $185.33{ }^{0} \mathrm{C}$ menjadi 160.67 ${ }^{0} \mathrm{C}$ atau penurunan kualitas minyak goreng curah yang dilihat dari penurunan titik asap adalah sebesar $13.31 \%$.

Pola penurunan temperatur titik asap minyak goreng curah yang dilakukan selama empat jam penggorengan pada suhu di atas $190{ }^{\circ} \mathrm{C}$ terlihat menurun dengan penurunan yang tidak linier. Hal ini juga terjadi karena dalam penggorengan kerupuk jalin setiap selang waktu satu jam sekali dilakukan penambahan minyak baru sebanyak $2 \mathrm{~kg}$. Melihat keadaan tersebut ternyata penambahan minyak baru yang dilakukan pada selang waktu satu jam sekali dalam penggorengan kerupuk jalin dapat meminimalisir penurunan titik asap minyak goreng. Penambahan minyak goreng juga dimaksudkan untuk memperbaharui minyak goreng baik secara kualitas maupun kuantitas. Sehingga penambahan minyak sangat berfungsi untuk mengoptimalkan proses penggorengan dan untuk memelihara mutu makanan yang digoreng (Sangdehi, 2005).

Hubungan korelasi titik asap dengan asam lemak bebas diperoleh nilai koefesien korelasi $(r)=-0,80$, yang 
menandakan bahwa hubungan titik asap dengan asam lemak bebas memiliki hubungan yang berbanding terbalik, yaitu semakin turun titik asap maka kadungan asam lemak bebas semakin meningkat.

\section{KESIMPULAN DAN SARAN}

\section{Kesimpulan}

* Bilangan asam dan asam lemak bebas minyak goreng curah selama penggorengan kerupuk jalin mengalami pola peningkatan yang tidak linier masing-masing sebesar $45.87 \%$ dan $51.40 \%$. Dilain pihak, pada titik asap mengalami penurunan yang tidak linier sebesar 13.31. Penurunan dan peningkatan tersebut mengindikasikan minyak goreng curah selama penggorengan kerupuk jalin mengalami penurunan kualitas yang dilihat dari bilangan asam asam lemak bebas dan titik asap. Pola peningakatan dan penurunan tidak linier disebabkan karena terjadi penambahan minyak baru setiap satu jam sekali yang berfungsi untuk menstabilkan minyak goreng baik secara kualitas maupun kuantitas

- Berdasarkan pengukuran kandungan bilangan asam, asam lemak bebas dan titik asap, diketahui bahwa minyak goreng curah masih layak pakai adalah pada 40 kali penggorengan selama 2.5 jam dengan kerupuk jalin sebanyak 100 $\mathrm{kg}$. Hal ini mengindikasikan bahwa kandungan bilangan asam $2.42 \%$ masih di bawah batas maksimal yaitu $2.5 \%$.

\section{Saran}

Sebaiknya penggunaan minyak curah apabila dilakukan penambahan ulang dengan volume minyak baru harus lebih banyak lagi pada pencampuran awal dan pada saat penambahan ulang serta waktu penambahan ulang agar dapat dipercepat sehingga kualitas minyak curah dapat lebih stabil. Perlu dilakukan penelitian lanjutan mengenai bahan yang digoreng dengan minyak curah yang dilakukan penambahan ulang.

\section{DAFTAR PUSTAKA}

Anonim, 2002. Kesehatan. http://www2.kompas.co,/kesehata n/news/0204/18/030145.htm. 25 Maret 2009

Atmojo, Lusiana Dwi. 2007. Pengaruh Subtitusi Tempe dengan Penggunaan Minyak Goreng Terhadap Kualitas Organoleptik dan Nilai Gizi Bolu Kukus .Skripsi, Jurusan Teknologi Jasa dan Produksi, Pendidikan Tata Boga, Fakultas Teknik Universitas Negeri Semarang

Berger, K.G. 2005. The Use of Palm Oil in Frying. Malaysian Palm Oil Promotion Council. Malaysia

Blumenthal. M. M. 1991. A New Look at The Chemistry and Physics of Deep Fat Frying. Food Technology. 45:68-71

Budiyanto. 1996. Soybean and Palm Olein Oils: Frying Performance and Characteristics of Fried Prawn Crackers. PhD. Diss. The University of Tennesse. Knoxville

Budiyanto, Devi Silsia dan Zulman Efendi. 2008. Perubahan Kandungan $\beta$-Karoten dan 
Kandungan Asam Lemak Bebas Minyak Sawit Merah Selama Pemanasan. Prosiding Seminar Nasional Sains dan Teknologi-II 2008. Universitas Lampung, 1718 November 2008

Deane, J. 2007. Smoke Point of Olive Oil.

http://www.oliveoilsource.com/ olive_oil smoke_point.htm. Januari 2010

Hariskal. 2008. Pengaruh Pemanasan Pada Minyak Goreng dan Minyak Goreng Bekas Pakai. Skripsi Fakultas Pertanian Universitas Bengkulu. Bengkulu (Tidak Dipublikasikan)

Jacobson, G.A. 1991. Quality control in deep-fat frying operations. Food Technol. 45: 72-74

Janika, R. 2008. Kajian Perubahan Kadar B-Karoten Asam Lemak Bebas dan Bilangan Peroksida Minyak Sawit Merah Selama Proses Pemanasan. Skripsi. Fakultas Pertanian. Universitas Bengkulu. Bengkulu (Tidak dipublikasikan)

Ketaren, S. 1986. Pengantar Teknologi Minyak dan Lemak Pangan. UIPress. Jakarta

Kurniawan. Yuniarto dan Sukmawaty, 2008. Penentuan Susut Mutu Fisik Minyak Goreng Dalam Operasi Penggorengan Hampa. Program Studi Teknik Pertanian Mataram. Mataram

Navas, J.A. A. Tres, R. Bou, R. Codony dan F. Guardiola. 2007. Optimization of Analytical Methods For The Assessment Of
The Quality Of Fats And Oils Used In Continuous Deep Fat Frying. Healt 58 (2)148-153

Sangdehi, Samira Kazemi. 2005. Quality Evaluation of Frying Oil and Chicken Nuggets VIS/NIR Hyperspectral Analysis. Thesis Departemen Bioresource Rancang-Bangun Mcgill Universitas Montreal, Quebec. Canada

Siahaan, D., S. Silalahi, M. E. Siregar. 2004. Studi Awal Kualitas Minyak Goreng Kelapa Sawit pada Penggorengan berulang Produk Tertentu.

http://www.iopri.org/index.php?o ption $=$ com_content\&ask $=$ section \&id=91\&Itemid=47. Juli 2008

Tseng, Y. C., R. Moreira, and X. Sun. 1996. Total Frying-use Time Effects on Soybean-oil Deterioration and on Tortilla Chips Quality. International Journal of Food Science and Technology. 31: 287-294.

Ramini. 2008. Kajian Perubahan Kualitas Minyak Goreng Kelapa Sawit Selama Proses Pemanasan. Skripsi Fakultas Pertanian Universitas Bengkulu. Bengkulu (Tidak Dipublikasikan)

White, P. J. 2007. Frying Performance of No-trans, Low-Linolenic Acid Soybean Oils. Journal of the AOCS.

Wiley, John dan Sons. 2009. Smoke Point. http://en.wikipedia.org/wiki/Smok e_point. 11 Desember 2010 
Winarno, F. G. 1997. Kimia Pangan

Dan Gizi. Gramedia Pustaka

Utama. Jakarta 